\title{
A Study on the Individual Factors Affecting the Performance of the Subjects in the Man-Machine Foreign Language Oral Test
}

\author{
Yong Fang ${ }^{1,2 *}$
}

\author{
${ }^{1}$ School of Foreign Languages, Jianghan University \\ ${ }^{2}$ School of Chinese Language and Literature, Central China Normal University \\ *Yong Fang. Email:875540144@qq.com
}

\begin{abstract}
Preference for oral test mode, test anxiety, self cognition of foreign language ability and foreign language acquisition background are several important factors affecting the performance of the subjects in an oral test. In this study, ten undergraduates and six teachers were recruited as subjects and examiners respectively to organize a simulated oral English test based on man-machine mode. The statistics and analysis of the experimental data show the following findings. Firstly, there is a slight significant difference between the preference degrees of advanced and intermediate English learners on man-machine mode, and the preference of the former is higher than that of the latter. Secondly, the subjects generally feel nervous and anxious in the test. Moderate anxiety actively promote the performance of candidates in the test. Thirdly, Subjects' self-assessment was significantly lower than examiners' scoring on them. It is speculated that the man-machine oral test reduces the subjects' recognition of their English ability, which is a negative impact on their foreign language acquisition process. Fourthly, the more hours the subjects spend learning and using English daily, the better they perform in the test. Repeated reinforcement of foreign language knowledge accelerates the process of acquisition.
\end{abstract}

Key words: man-machine mode, foreign language oral test, preference degree, test anxiety, self cognition of foreign language ability, foreign language acquisition background

\section{EXPLANATION OF THE EXPERIMENT}

In addition to the differences in candidates' foreign language ability, what other personal factors also affect their performances in the man-machine foreign language oral test? Yong Fang [1] analyzed the psychological state of the subjects during the test, collected data through the design and implementation of the simulated oral English test of man-machine mode, and carried out qualitative analysis and discussion on the personal factors that affect the subjects' oral performance in the man-machine test, which includes subjects' preference for oral test mode, their test anxiety, self cognition of foreign language ability, and foreign language acquisition background.

Five English majors and five non English majors undergraduates who had the experience of oral English test, and whose score were at the middle level, were recruited as subjects. The purpose of setting the range of the subject's oral proficiency is to avoid the ceiling effect caused by high oral ability, and the detecting failure caused by low oral ability. The experiment also recruited 6 teachers, including 3 native speakers of Chinese and 3 native speakers of English, as examiners to score the recorded materials. The experiment was conducted in a relatively closed and quiet environment. After the debugging of the experimental equipment, the subjects made impromptu English speeches according to the two topics given on the screen. Each topic has one minute for preparation and two minutes to deliver. There is a one minute interval between the two topics to prevent experimental fatigue. In order to prevent the possible influence of the order of the two topics on the oral performance, this experiment adopts the method of counterbalance test to collect data. All speeches were recorded as research data. After the oral test, the subjects completed a questionnaire concerning the test. The data concerning personal factors affecting the performance of the subjects in the test are analyzed and disclosed as follows. 


\section{SUBJECTS' PREFERENCE DEGREE FOR MAN-MACHINE MODE}

In the previous study by Yong Fang [1], it had been found that the subjects generally have no obvious preference for man-machine mode. In the early investigation, most of the subjects had participated in the man-machine mode oral test long time ago, so they may have a vague memory of the test experience. In view of this, ten subjects in this experiment were asked to evaluate their preference for the man-machine mode test immediately after having completed the stimulated test. It is reasonable to believe that, theoretically, these subjects, who had just completed the test, can best reflect their real experience.

Firstly, tendency of the subjects' preference for oral test of human-machine mode is drawn (see Figure 1). In order to explore whether the subjects' preference is related to their English ability, the subjects are grouped in advance when drawing Figure 1. On the $\mathrm{x}$-axis, subjects No.1 to No.5 are advanced English learners, and No.6 to No.10 are intermediate English learners. On the y-axis, the Likert 5-point system is used, in which 1 is the least favorite and 5 is the most favorite. In order to see the preference trend more intuitively, subjects of each group has been arranged from high to low according to their preference value in the group.

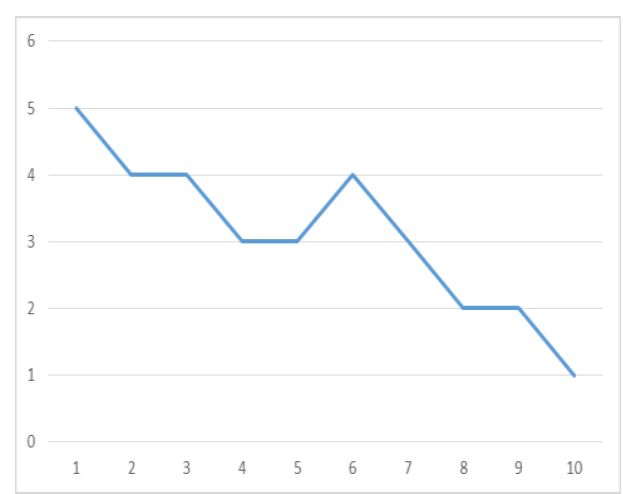

Figure 1 Tendency of the Subjects' Preference for Oral Test of Human-machine Mode

Figure 1 shows a clear downward sloping curve, which shows that the preference of advanced English learners is generally higher than that of intermediate English learners. In order to further discuss the statistical significance of the data, SPSS statistical analysis software was used to test the differences between groups, and the test results are in Table 1 and Table 2.

Table 1 Descriptive Data of Inter Group Difference Test Concerning Subjects' Preference

\begin{tabular}{|c|c|c|c|c|}
\hline & Number & Average Value & Standard Deviation & Standard Error \\
\hline Advanced English Learners & 5 & 3.8000 & .83666 & .37417 \\
\hline Intermediate English Learners & 5 & 2.4000 & 1.14018 & .50990 \\
\hline
\end{tabular}

Table 2 Inter Group Difference Test of the Subjects' Preference

\begin{tabular}{|c|c|c|c|c|c|c|c|}
\hline & \multicolumn{7}{|c|}{ Inter Group Mean Difference Test } \\
\cline { 6 - 8 } & $\mathrm{t}$ & $\mathrm{df}$ & $\begin{array}{c}\text { Significance } \\
\text { (bidirectional) }\end{array}$ & $\begin{array}{c}\text { Average } \\
\text { Difference }\end{array}$ & $\begin{array}{c}\text { Standard } \\
\text { Error } \\
\text { Difference }\end{array}$ & $\begin{array}{c}\text { 95\% Confidence Interval } \\
\text { of the Difference }\end{array}$ \\
\cline { 6 - 8 } & & & Lower & Upper \\
\hline $\begin{array}{c}\text { Advanced English } \\
\text { Learners--- } \\
\begin{array}{c}\text { Intermediate English } \\
\text { Learners }\end{array}\end{array}$ & 2.214 & 8 & .058 & 1.40000 & .63246 & -.05845 & 2.85845 \\
\hline
\end{tabular}

Table 1 shows that the average preference of advanced English learners $(\mathrm{N}=5$, Average Value $=3.80)$ is higher than that of intermediate English learners $(\mathrm{N}=5$, Average Value=2.40). However, table 2 shows a slightly significant difference in preference between the two groups, with Pearson value of $\mathrm{P}=.058$ and reliability value of $\mathrm{R}=0.62$, showing a moderate degree of reliability, which shows that the higher the foreign language proficiency, the higher the preference for the man-machine oral test mode. Since the subjects gave feedback immediately after the test, the author believes that above data truly represent the most intense and intuitive preference experience of the subjects. In the author's opinion, the reason behind the results is that subjects with higher the English proficiency are able to speak independently for up to two minutes without the help of communication objects' real-time information feedback. Therefore, they have a strong desire to express. However, those subjects who are limited by their English ability,their desire of expression are also inhibited. For them, the sense of frustration is far greater than the sense of achievement.

To sum up, the higher their English proficiency, the easier the candidates are to accept the man-machine oral 
test mode. According to the previous research stated in the literature review, test anxiety of candidates significantly affect their performance. Therefore, it is necessary to discuss the test anxiety of the subjects in the next part, and discuss whether the test anxiety is similar to personal English ability factor, and whether it is related to their preference of test mode.

\section{SUBJECTS' TEST ANXIETY}

Although it is still controversial whether the effect of test anxiety is positive or negative on the oral performance of the candidates, its significant presence in the test is generally accepted. The previous research on the man-machine mode points out that one of the most common reasons why it is not accepted by candidates is that it sets a very strict time limit, and candidates must complete their personal statements of the given topic within the specified time. Candidates have to bear the pressure of using the foreign language, at the same time, they have to bear the pressure of time control. The excessive pressure leads to the candidates' serious test anxiety [2].

In order to verify the correctness and universality of this research proposition, ten subjects in this experiment were asked to complete a questionnaire on their test anxiety. After referring to the questionnaire of Zhang Yanxia [3], three survey items about test anxiety were selected and edited into the questionnaire. Highly reliable Likert 5-point system with was adopted. The data analysis of the questionnaire is as follows.

Firstly, in order to verify the statistical reliability of the three questions, Cronbach's alpha reliability test was carried out. The test results are shown in Table 3 and table 4 respectively. Table 3 is the descriptive statistics, and Table 4 is the test results.

Table 3 Descriptive Data of Questionnaire Reliability Test

\begin{tabular}{|c|c|c|c|}
\hline Test Questions & $\begin{array}{c}\text { Average } \\
\text { Value }\end{array}$ & $\begin{array}{c}\text { Standard } \\
\text { Deviation }\end{array}$ & Number \\
\hline My heart beat hard just now in the test & 3.40 & .966 & 10 \\
\hline My mind became stiff during the test just now & 4.30 & .823 & 10 \\
\hline $\begin{array}{c}\text { When I took the test just now, my personal emotion affected my } \\
\text { performance }\end{array}$ & 3.30 & 1.337 & 10 \\
\hline
\end{tabular}

Table 4 Results of Questionnaire Correlation Test

\begin{tabular}{|c|c|c|c|c|}
\hline & $\begin{array}{l}\text { Cronbach's } \\
\text { Alpha }\end{array}$ & .735 & $\begin{array}{l}\text { Number of } \\
\text { Test } \\
\text { Questions }\end{array}$ & 3 \\
\hline & $\begin{array}{l}\text { Average Span } \\
\text { (If any single } \\
\text { item is } \\
\text { deleted) }\end{array}$ & $\begin{array}{l}\text { Total Floating Rate } \\
\text { of Test Questions (If } \\
\text { any single item is } \\
\text { deleted) }\end{array}$ & $\begin{array}{l}\text { Intra Group } \\
\text { Correlation of } \\
\text { Test } \\
\text { Questions }\end{array}$ & $\begin{array}{c}\text { Cronbach's } \\
\text { Alpha Value(If } \\
\text { any single item is } \\
\text { deleted) }\end{array}$ \\
\hline $\begin{array}{c}\text { My heart beat hard just now in } \\
\text { the test }\end{array}$ & 7.60 & 4.267 & .367 & .844 \\
\hline $\begin{array}{l}\text { My mind became stiff during the } \\
\text { test just now }\end{array}$ & 6.70 & 3.567 & .779 & .474 \\
\hline $\begin{array}{c}\text { When I took the test just now, my } \\
\text { personal emotion affected my } \\
\text { performance }\end{array}$ & 7.70 & 2.233 & .662 & .557 \\
\hline
\end{tabular}

Table 3 shows that the average responses of the subjects to the three questions concerning anxiety are 3.40 (standard deviation $=.966$ ), 4.30 (standard deviation $=.823)$ and 3.30 (standard deviation $=1.337)$. The middle figure is slightly high, while the other two are very close to each other. Table 4 further confirms that the three questions are closely related, showing that the answers to questions 2 and 3 are highly intra group correlated, and that after deleting any single item, the response reliability Cronbach's alpha value of question 1 and 3 is still high. In general, the overall Cronbach's alpha value of the three questions is .735 . Considering that, in the field of second language acquisition, the
Cronbach's alpha value higher than .6 is regarded as reliable, it is therefore considered that the test results shown in Table 4 has a high degree of statistical reliability. In other words, any item can reflect the test anxiety of the subjects. On the Likert 5 scale, the higher the value is, the higher the subjects' anxieties are.

Table 4 shows that the average test anxiety has exceeded $65 \%$ of the five point system. The response of the subjects for each question will be further analyzed and discussed. As for question 1, 50\% of the subjects thought that their hearts beat hard (5 points) or relatively hard ( 4 points) during the test, 1 person and 4 people respectively. For the remaining $50 \%$ of the subjects, 
$60 \%$ ( 3 person) chose to have a heart rate between normal and abnormal (3 points) during the test. No subject chose a heart rate that was exactly the same as usual ( 1 point). The above data show that the subjects generally feel nervous in the test.

As for the response of question 2, 50\% of the subjects thought that their thinking had become rigid in the process of the test ( 5 points). $60 \%$ of the remaining half basically agreed with the description (4 points), and the other $40 \%$ were neutral ( 3 points). The author thinks that the stronger the subjects experience the rigidity of thinking, the stronger their test anxieties are. The so-called blank mind can be regarded as the adverse effect of such test anxiety, and it affects the oral performance of the subjects directly.
As for the investigation of question 3 , compared with the feedback of the first two questions, the distribution of feedback information is relatively broad. Each option was chosen by 1 to 3 subjects. Among them, 2 person chose 5 points, 3 person chose 4 points, 3 person chose 3 points, 2 person chose 2 points, and 1 person chose 1 point. The major explanation for the balanced distribution is that question 3 is much more abstract than the first two, which leads to the subjects' confusion, and great differences in their choices. But one relevant data should be noted. The subjects' feedback of question 2 and 3 have statistical positive correlation significance, and its statistical analysis are shown in Table 5.

Table 5 Correlation Test of the Feedback of Question 1 and 3

\begin{tabular}{|l|c|c|}
\hline \multicolumn{2}{|c|}{} & $\begin{array}{c}\text { When I took the test just now, my personal emotions } \\
\text { affected my performance }\end{array}$ \\
\hline \multirow{3}{*}{\begin{tabular}{c} 
My mind became stiff during the $\begin{array}{c}.817^{* \star} \\
\text { test just now }\end{array}$ \\
\cline { 2 - 3 }
\end{tabular}} & $\begin{array}{c}\text { Pearson Correlation } \\
\text { (bidirectional) }\end{array}$ & .004 \\
\cline { 2 - 3 } & Number & 10 \\
\hline \multirow{2}{*}{ (b*. Correlation is significant at the 0.01 level (2-tailed). } & \\
\hline
\end{tabular}

Table 5 shows that there is a significant correlation between the two experiences in the test, namely, the rigid thinking and the influence of personal emotion. Pearson value is $\mathrm{p}=.004$ and the correlation is .817. On the other hand, there is no significant correlation between the feedback of question 1 and the feedback of the other two questions. This shows that question 2 and question 3 are closer to the negative effect caused by the test anxiety, while the inducement of question 1 is not completely due to test anxiety. The author thinks that the high concentration of attention of the subjects in the state of test, or even the excitement caused by its challenge, serve as the inducements. The basis of such speculation is that appropriate anxiety during the test can stimulate the students, resulting in their better L2 performances [4] [5] [6] [7]. Therefore, the author thinks that the heart rate acceleration caused by anxiety in the test does not necessarily impose a negative effect on the performance of the subjects. In the future, studies on the psychological or physiological symptoms of subjects who are experiencing test anxiety should be carried out, so as to explore both the negative effects and the positive effects caused by test anxieties.

\section{SUBJECTS' SELF COGNITION OF FOREIGN LANGUAGE ABILITY}

In order to explore the self cognition of the participants on their foreign language ability, the subjects are required to make self-assessment of their oral English ability. In order to explore the self cognition of their performance in the man-machine oral test mode, the questionnaire also requires the subjects to conduct a self-assessment on that. The two self-assessments were conducted in the form of Likert 5-point system, with 1 as the lowest score and 5 as the highest score.

The data show that the average score of the self-assessment of English ability of the subjects is 2 points $(\mathrm{N}=10)$, and the average score of the self-assessment of oral English performance in the test is 1.9 points $(\mathrm{N}=10)$. The intra group correlation test (paired samples correlations) shows that there is a significant correlation between the two, with Pearson value of $\mathrm{P}=.019$. This shows that the subjects believe that their performance in the man-machine test mode truly reflect their oral English ability. Table 6 shows the results of the above statistical analysis.

Table 6 Intra Group Correlation Test of Subjects' Self-assessment on their English Ability and Oral Performance

\begin{tabular}{|c|c|c|c|c|}
\hline \multicolumn{2}{|c|}{} & Number & Relevance & Significance \\
\hline Subject Group & $\begin{array}{c}\text { Self-assessment on their English Ability and Oral } \\
\text { Performance in the Test }\end{array}$ & 10 & .719 & .019 \\
\hline
\end{tabular}


Secondly, the subjects were divided into senior English learners group and intermediate English learners group according to their English ability, and the differences between the groups were tested. The results shows that there is no significant difference between the two groups in English proficiency self-assessment and performance self-assessment. The average self-assessment of English proficiency in the senior group is $2.20(\mathrm{~N}=5)$, and that of the intermediate group was $1.80(\mathrm{~N}=5)$. The average self-assessment on the performance of the senior group is $1.80(\mathrm{~N}=5)$, and the intermediate group is $2.00 \quad(\mathrm{~N}=5)$. The difference between the two groups was $\mathrm{P}=.47$ and $\mathrm{P}=.61$ respectively. This shows that there is no significant difference between the two groups in terms of self-assessment, and both groups underestimate their English ability and performance in the exam. Table 7 shows the above statistical results.

Table 7 Inter Group Differences Test of Subjects' Self-assessment on English ability and Oral Performance

\begin{tabular}{|c|c|c|c|c|c|c|c|}
\hline & \multicolumn{7}{|c|}{ Inter Group Difference of Mean Value $t$-test } \\
\hline & \multirow[t]{2}{*}{$\mathrm{t}$} & \multirow[t]{2}{*}{$d f$} & \multirow{2}{*}{$\begin{array}{l}\text { Significance } \\
\text { (bidirectional) }\end{array}$} & \multirow{2}{*}{$\begin{array}{l}\text { Average } \\
\text { difference }\end{array}$} & \multirow{2}{*}{$\begin{array}{l}\text { Standard } \\
\text { Error }\end{array}$} & \multicolumn{2}{|c|}{$\begin{array}{l}\text { 95\% Confidence Interval } \\
\text { of the Difference }\end{array}$} \\
\hline & & & & & & Lower & Upper \\
\hline $\begin{array}{l}\text { Self-assessment on } \\
\text { English Ability }\end{array}$ & 8 & .471 & .400 & .529 & -.820 & \multicolumn{2}{|c|}{1.620} \\
\hline $\begin{array}{l}\text { Self-assessment on Oral } \\
\text { Performance }\end{array}$ & 8 & .608 & -.200 & .374 & -1.063 & \multicolumn{2}{|c|}{.663} \\
\hline
\end{tabular}

Another important reference that can be used to explore the reasons for the differences between the two groups is the examiner's scoring on the subjects. It is assumed that if the examiner's scoring is significantly higher than the subjects' self-assessment of their English ability, it proves that the subjects underestimate their English ability. It should be noted that since it has been confirmed that there is no significant difference between the self-assessment of English ability and the self-assessment of performance, the self-assessment of the subjects on their English ability can be compared with that of the examiners. Technically, the examiners use 10 points scoring system in the experiment, but the self-assessment is 5 points system. It is necessary to multiply the examiner's scoring by $50 \%$ in advance to make them comparable. In the statistical analysis, the oral performance of the subjects is regarded as an independent variable, while the assessment made by the native Chinese examiner, the native English examiner and the subjects themselves are regarded as dependent variables. Table 8 shows the result of statistical analysis after data processing.

Table 8 Difference Analysis on Oral Performance Assessment between Examiners and Subjects

\begin{tabular}{|c|c|c|c|c|c|c|c|c|c|}
\hline & & \multicolumn{5}{|c|}{ Inter Group Differences } & \multirow{3}{*}{$\mathrm{t}$} & \multirow{3}{*}{ df } & \multirow{3}{*}{$\begin{array}{l}\text { Significance } \\
\text { (bidirectional) }\end{array}$} \\
\hline & & \multirow[t]{2}{*}{$\begin{array}{l}\text { Average } \\
\text { Number }\end{array}$} & \multirow[t]{2}{*}{$\begin{array}{l}\text { Standard } \\
\text { Deviation }\end{array}$} & \multirow{2}{*}{$\begin{array}{l}\text { Mean } \\
\text { Standard } \\
\text { Error }\end{array}$} & \multicolumn{2}{|c|}{$\begin{array}{l}95 \% \text { Confidence } \\
\text { Interval of the } \\
\text { Difference }\end{array}$} & & & \\
\hline & & & & & Lower & Upper & & & \\
\hline $\begin{array}{c}\text { Group } \\
1\end{array}$ & $\begin{array}{c}\text { Native English Examiners' } \\
\text { Scoring - Subjects' Self } \\
\text { Assessment }\end{array}$ & 1.23500 & .90260 & .28543 & .58932 & 1.88068 & 4.327 & 9 & .002 \\
\hline $\begin{array}{l}\text { Group } \\
2\end{array}$ & $\begin{array}{c}\text { Native Chinese } \\
\text { Examiners' Scoring - } \\
\text { Subjects' Self } \\
\text { Assessment }\end{array}$ & 1.17500 & .81578 & .25797 & .59143 & 1.75857 & 4.555 & 9 & .001 \\
\hline
\end{tabular}

It can be concluded from Table 8 that the average scores given by native English examiners and native Chinese examiners are significantly higher than the subjects' self-assessment on their English ability. The Pearson value of the former is $p=.002$, and that of the latter is $p=.001$. The reliability index is $r=0.82$ and $\mathrm{R}=0.84$ respectively, which indicates high reliability.

The above statistical results confirm the second possibility mentioned above, that is, the subjects significantly underestimate their actual oral English ability. This shows that the man-machine mode has a significant negative effect on the examinees' self cognition and affirmation of their English ability, which will lead to sense of psychological frustration, losing confidence in learning, weakening their learning motivation, and affecting the process of their foreign language acquisition. As for the cause of this phenomenon, the author speculates that it is due to the lack of interaction in the man-machine mode. Examinees are unable to find help from the outside 
when they encounter difficulties in expression. Under such circumstances, if the part of the expression cannot be determined to be correct, even if the expression is correct, it will lead to examinee's self-doubt. To sum up, the use of man-machine oral test mode results in candidates' underestimating of their oral English ability, the impact of which is greater on candidates with low level of foreign language ability.

\section{SUBJECTS' PERSONAL ENGLISH LEARNING BACKGROUND}

The above analysis and discussion has clarified that there is a significant positive correlation between the subjects' personal English ability and their oral performance, which is a general conclusion. In this section, quantitative research method will be used to analyze the specific aspects of the correlation between the subjects' personal English learning background and their performance in the man-machine oral test mode.

From the perspective of quantitative study, the questionnaire asked the subjects to provide the number of hours using or learning English per week, and the number of hours communicating in English per week. In the questionnaire, the subjects have been informed that the number of hours in the previous data does not include the number of hours of communicating in English. In addition, considering the individual differences and the difficulty in accurately calculating the number of hours, the questionnaire did not require the subjects to provide accurate hours. Instead, the questionnaire used 5-point system options, and each option represents a range of one hour. Table 9 shows the data feedback of ten subjects.

Table 9 Subjects' Learning and Using of English

\begin{tabular}{|c|c|c|c|c|c|c|c|c|c|c|}
\hline Subject Number & 1 & 2 & 3 & 4 & 5 & 6 & 7 & 8 & 9 & 10 \\
\hline $\begin{array}{c}\text { Number of Hours using or learning English } \\
\text { Per Week }\end{array}$ & 3 & 4 & 1 & 1 & 2 & 4 & 1 & 1 & 1 & 4 \\
\hline $\begin{array}{c}\text { Number of Hours Communicating in English } \\
\text { Per Week }\end{array}$ & 2 & 3 & 1 & 1 & 1 & 3 & 1 & 1 & 1 & 3 \\
\hline $\begin{array}{c}\text { Grouping of Subjects' English proficiency b } \\
\text { (1) }\end{array}$ & 1 & 2 & 2 & 1 & 1 & 2 & 2 & 2 & 1 \\
\hline
\end{tabular}

Please note that, a. 1 = least hours; $5=$ the most hours; Please refer to the appendix for the corresponding relationship between specific value and hours; and b. 1 = Advanced English learners; 2 = Intermediate English learners

Table 9 shows that the number of hours per week for Advanced English learners to learn English and to communicate in English orally are far more than those for intermediate English learners. The analysis proves a positive correlation between the English learning of the subjects and the scoring of the examiners. Table 10 shows the test results of this statistical analysis. It should be noted that since the 5-point scale represents the subjects' number of hours, in order to increase the reliability of statistics, the correlation test uses the nonparametric test (Spearman test).

Table 10 Correlation Test between Subjects' English learning and Use and their Oral Test Scores

\begin{tabular}{|c|c|c|c|c|}
\hline & & & $\begin{array}{l}\text { Number of Hours } \\
\text { Per Week Using or } \\
\text { Learning English } \\
\end{array}$ & $\begin{array}{c}\text { Number of Hours Per } \\
\text { Week Communication in } \\
\text { English }\end{array}$ \\
\hline \multirow{9}{*}{$\begin{array}{c}\text { Spearman } \\
\text { Test }\end{array}$} & \multirow{3}{*}{$\begin{array}{l}\text { Native English } \\
\text { Examiner }\end{array}$} & Relevance & $.801^{\star *}$ & $.637^{*}$ \\
\hline & & $\begin{array}{l}\text { Significance } \\
\text { (bidirectional) }\end{array}$ & .005 & .048 \\
\hline & & Number of Subjects & 10 & 10 \\
\hline & \multirow{3}{*}{$\begin{array}{l}\text { Native Chinese } \\
\text { Examiner }\end{array}$} & Relevance & $.861^{* *}$ & $.737^{\star}$ \\
\hline & & $\begin{array}{l}\text { Significance } \\
\text { (bidirectional) }\end{array}$ & .001 & .015 \\
\hline & & Number of Subjects & 10 & 10 \\
\hline & \multirow{3}{*}{$\begin{array}{c}\text { Number of Hours Per } \\
\text { Week Using or } \\
\text { Learning English }\end{array}$} & Relevance & 1.000 & $.945^{\star *}$ \\
\hline & & $\begin{array}{l}\text { Significance } \\
\text { (bidirectional) }\end{array}$ & . & .000 \\
\hline & & Number of Subjects & 10 & 10 \\
\hline
\end{tabular}

From the observation of table 10, it can be drawn that the scores given by both native English examiners and native Chinese examiners are positively correlated with the hours of English learning and communication. 
The two Pearson values of the former are $p=.005$ and $\mathrm{p}=.048$ respectively, and the two Pearson values of the latter are $\mathrm{p}=.001$ and $\mathrm{P}=.015$ respectively. The intra group correlation test on the number of hours of English learning per week and the number of hours of oral English communication per week reached a very significant level $(\mathrm{P}<0.01)$. This is in line with the expectation of the general foreign language acquisition theory. The more learners use the foreign language, the closer their interlanguage is to the foreign language. And the higher their foreign language ability, the closer their foreign language performance is to the native speaker.

\section{CONCLUSION}

In this study, quantitative analysis is used to discuss the personal factors affecting subjects' performance in man-machine foreign language test. The conclusion are as follows. 1, SPSS analysis shows that there is a slightly significant difference between advanced English learners and intermediate English learners in their preference of man-machine mode oral test, and the preference of the former is higher than that of the latter. 2, Generally speaking, the subjects generally feel nervous and anxious in the man-machine oral test mode, which is embodied in the rapid heartbeat, rigid thinking and nervousness. There is a significant correlation between rigid thinking and the negative effect of emotion on oral performance, but there is no significant correlation between the physiological response of heart rate acceleration and the above two. 3, The subjects' self-assessment on their English ability is significantly lower than that of the examiners. It is reasonable to speculate that the man-machine oral test mode may affect subjects' English learning enthusiasm, and brings negative impact on their process of foreign language acquisition. 4, Subjects spending more hours on learning and using English daily performs better in the test. This finding is in line with the expectation that repeated reinforcement of the use of foreign language knowledge accelerates learners' acquisition process.

\section{REFERENCES}

[1] Yong, Fang. An Experimental study on the effectiveness of oral tests for Chinese learners of English, in: Doctoral Dissertation, Central China Normal University, May 2015.

[2] Shi, F. Exploring Students' Anxiety in Computer-based Oral English Test. Journal of Language Teaching and Research, 3(3), 446-451, 2012.

[3] Zhang Yanxia. A Study of the Candidates' Test Anxiety in the CET-SET Context, in: Master Dissertation, Chongqing University, Nov, 2004

[4] Chastain, K. M. (1975). Affective and ability factors in second language acquisition. Language Learning, 25, 153-161.

[5] Alpert, R., \& Haber, R. Anxiety in academic achievement situations [J]. Journal of Abnormal and Social Psychology, 1960, 61: 207-215.

[6] Kleinmann, H. (1977). Avoidance behaviour in adult second language acquisition. Language Learning, 27, 93-107.

[7] Scovel, T. (1978). The effect of affect on foreign language: A review of the anxiety research. Language Learning, 28, 129-142. 